\title{
Discours
}

Revue de linguistique, psycholinguistique et

informatique. A journal of linguistics, psycholinguistics and computational linguistics

$18 \mid 2016$

Varia

\section{Additive Linking in Second Language Discourse: Lexical, Syntactic and Discourse Organizational Choices in Intermediate and Advanced Learners of L2 German with L1 French}

Audrey Bonvin and Christine Dimroth

\section{OpenEdition}

\section{Journals}

Electronic version

URL: http://journals.openedition.org/discours/9142

DOI: 10.4000/discours.9142

ISSN: 1963-1723

\section{Publisher:}

Laboratoire LATTICE, Presses universitaires de Caen

\section{Electronic reference}

Audrey Bonvin and Christine Dimroth, «Additive Linking in Second Language Discourse: Lexical, Syntactic and Discourse Organizational Choices in Intermediate and Advanced Learners of L2 German with L1 French », Discours [Online], 18 | 2016, Online since 16 September 2016, connection on 01 May 2019. URL : http://journals.openedition.org/discours/9142 ; DOI : 10.4000/discours.9142 

Revue de linguistique, psycholinguistique et informatique

Additive Linking in Second Language Discourse: Lexical, Syntactic and Discourse Organizational Choices in Intermediate and Advanced Learners of L2 German with L1 French

\author{
Audrey Bonvin \\ Institute of Multilingualism \\ University of Fribourg \\ Christine Dimroth \\ University of Münster
}

Audrey Bonvin, Christine Dimroth, «Additive Linking in Second Language Discourse: Lexical, Syntactic and Discourse Organizational Choices in Intermediate and Advanced Learners of L2 German with L1 French », Discours [En ligne], 18 | 2016, mis en ligne le 16 septembre 2016. 



\title{
Additive Linking in Second Language Discourse: Lexical, Syntactic and Discourse Organizational Choices in Intermediate and Advanced Learners of L2 German with L1 French
}

\author{
Audrey Bonvin \\ Institute of Multilingualism \\ University of Fribourg \\ Christine Dimroth \\ University of Münster
}

This paper reports results from a study on the acquisition of additive scope particles as a means to enhance discourse coherence by French learners of German as a second language.

It addresses the questions of which additive devices intermediate and advanced learners produce; which possibilities of syntactic integration in relation to the added constituent they use; and whether they choose target-like information units in order to establish additive relations across utterances. Oral production data from an elicited discourse production study reveal that the form of the additive expressions among advanced learners nearly always corresponds to the pattern preferred in the target language without, however, tapping its full potential. Rather, learners overuse options that are formally but not functionally similar in both languages.

This uniform behavior at the utterance level does not go hand in hand with target-like preferences for discourse organization. Native speakers of German tend to construe stretches of discourse as an answer to an implicit YES/NO question. They focus on the occurrence of events and use the assertion component to establish links and comparisons across utterances. Native speakers of French, on the other hand, prefer to construe utterances as answering implicit Wh-questions, thereby focusing discourse entities and establishing contrasts between them.

Based on their first language's entity-based utterance organization, even advanced second language learners of German are shown to use a hybrid system, establishing mainly entity-based and only a few assertion-based discourse relations.

Keywords: additive particles, information structure, discourse, second language acquisition, quaestio

Cet article présente les résultats d'une étude sur l'acquisition des particules de portée additives comme moyen de renforcer la cohésion discursive, en allemand langue seconde, par des apprenants francophones.

L'étude cherche à déterminer:1) quelles structures additives sont produites par des apprenants (niveau intermédiaire et avancé); 2) comment ils intègrent, au niveau syntaxique, ces structures additives par rapport à l'élément de l'énoncé auquel elles sont associées; 3) si les apprenants choisissent les mêmes unités informationnelles que les locuteurs natifs de la langue cible pour établir la relation additive inter-énoncés. Les données analysées, issues d'une tâche de production orale, révèlent que la forme des expressions additives chez les apprenants avancés correspond presque toujours au schéma favorisé dans la langue cible, sans cependant exploiter tout son potentiel. 
Plus précisément, les apprenants font un usage excessif des options qui sont formellement, mais pas fonctionnellement, similaires dans les deux langues.

Si les apprenants ont un comportement uniforme et similaire à celui des natifs au niveau de l'énoncé, ils ne suivent pas les préférences des locuteurs natifs au niveau de l'organisation discursive. Les locuteurs natifs de l'allemand ont tendance à construire des séquences discursives comme une réponse à une implicite "question oui/non». Ils se concentrent sur le fait qu'une action / un événement ait lieu ou non et utilisent l'élément d'affirmation pour établir des liens et des comparaisons inter-énoncés. Les locuteurs natifs du français, de leur côté, préfèrent construire des énoncés comme s'ils répondaient à une implicite question ouverte (Wh-question). Ils mettent ainsi l'accent sur les entités (protagonistes) du discours et établissent des contrastes entre elles. Se référant à l'organisation d'énoncés typique de leur première langue, les apprenants de l'allemand langue seconde utilisent, même à un stade d'apprentissage avancé, un système hybride qui établit majoritairement des relations discursives basées sur l'entité et seulement peu de relations basées sur l'affirmation du déroulement de l'action.

Mots clés: particules additives, structure informationnelle, discours, acquisition d'une langue seconde, quaestio

\section{Introduction}

Solving a complex verbal task such as telling a story involves the selection of information from different conceptual domains (e.g., times, places, entities, situations, etc.) and the encoding of relations between them. Within a sentence, a particular situation can be asserted to hold for an entity at a given time and place. Across sentences, information from the relevant conceptual domains can be linked in different ways. Time spans or discourse entities, for example, can be marked as being maintained, or different, or in contrast to time spans or discourse entities mentioned earlier. Without such markings, a task such as describing a picture or telling a story would result in a sequence of isolated utterances rather than a connected discourse or text. Prior research (von Stutterheim et al., 20I3) suggests that the selection of information units (e.g., protagonist, time) that speakers exploit to create coherence relations across utterances is at least partly dependent on the language specific inventories of grammatical categories (syntactic properties of subject, tense, aspect, etc.) in their language.

Second language $\left(\mathrm{L}_{2}\right)$ learners therefore do not only have to acquire the rules underlying the construction of sentence level structures in their target language, they also have to acquire the subtle regularities of coherence marking across utterances. Flecken et al. (2013) discuss a number of recent studies on the L2 acquisition of discourse organization and conclude that the acquisition of target language lexical or grammatical properties does not necessarily entail a target-like discourse organization. The task of acquiring the formal expression of a grammatical category, e.g., the progressive aspect in L2 English, is different from the task of identifying and applying the principles guiding the function of the progressive aspect in the temporal structure of a narration. Furthermore, first language $(\mathrm{LI})$ organizational principles are assumed to be deep-rooted and $\mathrm{L}_{\mathrm{I}}-\mathrm{L}_{2}$ differences in discourse organization are assumed to be harder to detect than surface differences in grammatical form. An 
attempt by advanced L2 learners to restructure discourse in accordance with the target language's grammatical properties is thus likely to result in a hybrid system involving $L_{1}$ as well as L2 organizational principles (Flecken et al., 2013).

Additive particles such as English too, French aussi, or German auch play an important role in information organization. They typically occur when speakers deal with information that is partly similar and partly different from the context as in example [I] below.

[I] Paul has a bike, too.

The sentence asserts that Paul has a bike and presupposes that either somebody different from Paul has a bike or that Paul owns something different from a bike ${ }^{1}$. Both of the potentially implied propositions are equally likely - in fact they are both trivially true. When a context sentence like [2] is available, it is easy to see what the relevant information is to which part of [I] is then "added".

[2] Mary has a bike.

Intuitively, the function of too in [I] in the context of [2] is to signal that Paul is added to the group of bike-owners to which at least Mary and maybe other contextually relevant people belong. A comparison with the preceding context thus helps to understand how the sentence splits up into similar and dissimilar information and to identify the information that is actually affected by the particle's additive meaning (i.e., the added constituent).

A prominent way of approaching the flow of information across utterances is to understand discourse as an answer to an underlying question that guides the way in which speakers organize information in subsequent utterances. These implicit questions have been labelled question under discussion (Roberts, 20I2; Clifton \& Frazier, 2012) or quaestio (von Stutterheim \& Klein, 2002; von Stutterheim \& Carroll, in press) ${ }^{2}$.

The default quaestio underlying a narrative stretch of discourse is construed as What happened then to X? (von Stutterheim \& Klein, 2002). This quaestio establishes the information belonging to the topic component of the responding discourse

1. As pointed out by an anonymous reviewer, the scope of too in example [I] can also be larger. The sentence could, for example, presuppose that Paul has another property, e.g., be a vegetarian, to which bike-owning is added.

2. A quaestio is an implicit question that is not answered by a single utterance, but by the core (the so-called main structure) of a discourse. Discourse types can be defined this way: the main structure of a narration is always going to relate events to topical time spans, for example. The question under discussion (QUD) does not distinguish between main-structure and side-structure, but tries to capture the dynamic development of the so-called common ground in a dialogue. The aim is to model the information flow between speaker and hearer by reconstructing the questions and sub-questions talked about at each moment. In the current study, we use the quaestio-model since we are dealing with rather monologic discourse produced in response to a question (quaestio) that was explicitly formulated at the outset. 
(temporal intervals and protagonists about which information is required) and it also determines referential movement, e.g., that each bounded event in a series occupies a new time span if nothing else is specified. Importantly, however, the distribution of information can also deviate from the scheme projected by the quaestio. This is for example the case when situations with similar descriptive properties are claimed to hold for two different topics.

[3] Peter and Pia met at the restaurant.

Peter insulted the waiter.

Pia insulted the waiter.

With appropriate additive marking of the last sentence (Pia insulted the waiter too) the discourse in [3] would be more coherent. Different information components can be used to achieve this. The information flow can be organized such that the entities are construed as alternatives to each other, as if the speaker were replying to an underlying subject Wh-question of the sort Who (else) did X? In order to signal such an information flow, the structures in [4a] in German or [4b] in French can be used.

[4a] Auch Pia hat den Kellner beleidigt.

Also Pia has the waiter insulted.

'Pia insulted the waiter, too.'

[4b] Pia aussi a insulté le serveur.

Pia also has insulted the waiter.

'Pia insulted the waiter, too.'

Note that discourse coherence does not necessarily require an additive particle, but can also be achieved via other lexical means, as for example in [4c].

[4c] Pia à son tour a insulté le serveur.

Pia at her turn has insulted the waiter.

'Then Pia in turn insulted the waiter.'

In the following, solutions such as in [4a-c] will be called entity-based because the subject Wh-question evokes alternative entities. One of them is selected in the response and highlighted as the new information answering the underlying question.

A different information flow is signalled when [3] is conceived as an answer to a Wh-question targeting the predicate (What did Pia do?). The information could be rendered as in $[5 \mathrm{a}]$ or $[5 \mathrm{~b}]$ :

[5a] Pia hat dasselbe getan.

'Pia did the same.'

[5b] Pia a fait la même chose.

'Pia did the same.' 
Utterances adopting this solution, that will be called similarity marking in the following, deviate only marginally from the default information structure for narrative discourse (What happened then to X?). As in the default case, the predicate presents the information that corresponds to the Wh-word of the question. At the same time the lexical specification of the predicate (do the same) anaphorically refers to an earlier token of a predicate with similar properties ${ }^{3}$.

Finally, [3] could also be construed as an answer to a polar question. In the relevant context, we know that Peter insulted the waiter. We also know that Pia was at the restaurant together with Peter, but we do not know her reaction yet and could thus be inclined to formulate an answer to an implicit question like What about Pia, did she insult the waiter? If a speaker wants to answer in the affirmative (i.e., convey the same information as in [4] and [5]), additivity could be expressed as in $[6 \mathrm{a}]$ or $[6 \mathrm{~b}]$.

[6a] Pia hat auch/ebenfalls einen Kellner beleidigt.

Pia has also/likewise a waiter insulted.

'Pia insulted a waiter too.'

[6b] Pia a aussi/également insulté un serveur.

Pia has also/likewise insulted a waiter.

'Pia insulted a waiter too.'

Since the answer alternatives opened by the polar question are restricted to (affirmative) assertion and negation, this solution will be called assertion-based. In German, auch has to be marked by a focal pitch accent when it appears in a post-finite position to the right of the added constituent as in [6a]. The particle has been analyzed as a focus (Féry, 2012) instantiating the affirmative alternative in a potential affirmation-negation contrast (Krifka, 1999; Dimroth, 2004).

From prior cross-linguistic research we know that auch is much more frequent than aussi in written (Blumenthal, 1985) as well as spoken language (Benazzo \& Dimroth, 20I5; Dimroth \& Benazzo, accepted) while similarity marking as in [5] occurs more frequently in French than in German (Dimroth \& Benazzo, accepted). The latter studies also found that speakers of German had a preference for the assertion-based integration of auch, whereas speakers of French used this option less frequently than the entity-based integration of aussi. Additive particles are used to establish links between information units in discourse, but the type of information selected (reflecting variants of the quaestio) is not the same across languages. Looking at additive and contrastive discourse relations in Italian and French as opposed to German and Dutch, Dimroth et al. (2010: 3340) speak about a "Romance way" and a "Germanic way".

3. Note that the predicate does not have to be identical. It is sufficient for it to be equated in the view of the speaker. This holds for sentences with additive particles as well. Example [3] would also be coherent if the last sentence was Pia was very rude too. 
French and German also differ on the level of utterance structure. The examples in [4] and [6] show that additive particles are syntactically relatively mobile in both languages. In addition to the positions exemplified there, an utterance final position similar to English too is possible in French, but not in German.

[7] Pia est partie l'insulter aussi.

Pia left to insult him as well.

'Pia started insulting him as well.'

The position of aucb/aussi in a sentence helps to identify the added constituent, although there is no one-to-one mapping between form and function ${ }^{4}$. Table I summarizes the possibilities for the two languages.

Whereas the subject constituent potentially followed by an entity-based aussi always precedes the finite verb (Table I) in French (subject-verb-object, SVO), the subject can follow the finite verb in German due to the "verb second" (V2) constraint. The additive particle then nevertheless precedes the added constituent in an entity-based construction such as [8a], or follows it in an assertion-based construction such as $[8 \mathrm{~b}]$.

[8a] Dann hat auch Pia einen Kellner beleidigt. = pre-posed

Then has also Pia a waiter insulted.

'Then Pia insulted a waiter too.'

[8b] Dann hat Pia auch einen Kellner beleidigt. = post-posed

Then has Pia also a waiter insulted.

'Then Pia insulted a waiter too.'

\begin{tabular}{|l|l|l|l|l|l|l|l|}
\hline & \multicolumn{2}{|l|}{$\begin{array}{l}\text { Adjacent to added NP: } \\
\text { entity-based }\end{array}$} & $\begin{array}{l}\text { Post-finite, } \\
\text { post-posed } \\
\text { to added NP: } \\
\text { assertion- } \\
\text { based }\end{array}$ & Final \\
\hline German & auch & Pia & & hat & auch & $\begin{array}{l}\text { einen } \\
\text { Kellner } \\
\text { beleidigt }\end{array}$ & \\
\hline French & & Pia & aussi & a & aussi & $\begin{array}{l}\text { insulté } \\
\text { un serveur }\end{array}$ & aussi \\
\hline
\end{tabular}

Table 1. "German-only", "French-only" and shared positions (grey cells) for additive particles in sentences with the subject noun phrase (NP) as added constituent

4. Some languages (e.g., Italian; Andorno, 1999) have very transparent rules for position-to-function mapping; basically the additive particle anche always directly precedes the added constituent. 
Furthermore, there are variants of the entity-based construction in French, where aussi plus the added constituent (a contrastive pronoun) are placed in different syntactic positions.

[9a] Pia a elle aussi insulté un serveur. Pia has she too insulted a waiter.

'Pia insulted a waiter too.'

[9b] Pia a insulté un serveur elle aussi. Pia has insulted a waiter she too. 'Pia insulted a waiter too.'

In this paper we inquire whether French learners of German as a second language at different proficiency levels have acquired the target-like frequency and placement possibilities for additive particles and whether they have reorganized discourse structure according to the assertion-based preferences attested in German.

Ringbom and Jarvis (2009) suggest that transfer is likely to occur because L2 learners constantly look for similarities between their Li and what they have already learnt of the target language. This leaves it open, however, on which level learners might try to find such similarities. If French learners of German looked for overlap on the form level the greater frequency of additive particles in German might go unnoticed and learners might use additive particles in shared positions at the expense of target language specific ones. If French learners of German were seeking overlap on the level of discourse organization they might overuse entity-based additive markings that exist in both languages but are dispreferred in German in comparison to assertion-based additive relations.

In the current study we investigate oral discourse data (film retellings) elicited from native speakers of French and German as well as two groups of learners with Li French and different proficiency levels in German as a second language (levels $\mathrm{B}_{1} / \mathrm{B}_{2}$ vs. $\mathrm{C}_{1} / \mathrm{C}_{2}$ according to the Common European Framework of Reference for Languages [CEFRL]). All learners had started learning German in their postpuberty school years in France and were living in Germany for a stay abroad at the time of testing.

In Section 2, we will formulate more concrete research questions and develop hypotheses on the basis of prior research. The methods and results of our empirical study will be presented in Section 3, followed by a discussion and conclusions in Section 4 .

\section{Background, research questions, and hypotheses}

In this section we will summarize prior research concerning (i) additive particles as opposed to other lexical devices expressing additive relations, (ii) the syntactic integration of French and German additive particles in relation to the added 
constituent, and (iii) the link between the utterances' information structure and discourse organization on a more global level. We will formulate research questions in relation to (i)-(iii) and present hypotheses for second language acquisition on the basis of assumptions on cross-linguistic influence. Points (i) and (ii) mainly pertain to the form of utterances; point (iii) addresses some consequences for discourse organization.

\subsection{Additive particles vs. other lexical devices for additive linking}

Recent semantic accounts treat additive particles as presupposition triggers that are obligatory when their presuppositions are satisfied (Krifka, 1999; Sæbø, 2004; Amsili $\&$ Beyssade, 2oıо; Eckardt \& Fränkel, 20I2), i.e., when the contextual information they evoke is explicitly spelled out in the preceding context. Obligatory uses are often exemplified with stretches of discourse such as [Io] (from Amsili \& Beyssade, 20IO), where the presupposition of aussi in [Iob] that some contextually relevant person other than Marie is sick is explicitly spelled out in [Ioa].

[roa] Jean est malade.

Jean is sick.

[rob] Marie est malade aussi.

Marie is sick too.

According to the above mentioned accounts obligatoriness results from the hearer's responsibility to prevent the listener from drawing unwarranted inferences that would arise in the absence of the particle. Without the additive particle, [Iob] could be interpreted as a correction of [Ioa], i.e., signalling that Marie is the only sick person in the relevant context (Amsili \& Beyssade, 2oro; Eckardt \& Fränkel, 20I2). A related explanation (Krifka, I999; Sæbø, 2004) assumes that after hearing the utterance in [Ioa] about Jean, listeners expect that the speaker will make distinct claims about alternative topics under discussion (otherwise Jean and Mary are sick would be a much more economical solution). The additive particle in [Iob] overtly signals a violation of the distinctiveness constraint, thereby again preventing hearers from drawing wrong inferences.

Amsili and Beyssade (2010) show that the degree of obligatoriness is mediated by discourse. An enumeration as in [II] (from Amsili \& Beyssade, 20Iо), for example, overwrites the above-mentioned constraints, and additive particles are no longer necessary for discourse coherence.

[II] Jean est malade, Marie est malade, Paul est malade, tout le monde est malade alors! John is sick, Marie is sick, Paul is sick, everybody is sick then!

In an empirical study, Eckardt and Fränkel (2012) show that this is also true when particular instructions influence discourse structure. In German retellings of short picture stories they found that additive particles were much more frequent 
when speakers had been instructed to write a story in comparison to a secret agent's protocol that specifies individual events in relation to pre-established time units (9:0o Fred strickt. Io:0o Otto putzt sich die Zäbne. II:oo Otto liest. I2:0o Fred putzt sich die Zäbne; Eckardt \& Fränkel, 2012: I808). These observations do not explain, however, why the exact same discourse type with the same content can elicit a different amount of additive particles in different languages. Everything else being equal additive particles seem to be "more obligatory" in German than in French (Blumenthal, 1985; Benazzo \& Dimroth, 2015) 5 .

In the current study we first want to verify whether frequency differences between German and French can be found if we only consider directly adjacent contexts such as [Io] for which the literature has claimed additive particles to be obligatory. Against this background we will investigate the frequency of auch as opposed to other or no markings produced by the two groups of learners.

\section{Research questions}

Do L2 learners of German with Li French match the frequency of additive particles displayed by native speakers of German? Do they use other markings, and if so, are these similar to the ones used by native speakers of French? Does the learner behavior change with increasing overall proficiency?

Prior research indicates that matching the target frequency of additive particles is a challenging task for $\mathrm{L}_{2}$ learners. Based on data from very advanced L2 learners of Italian with Li German or French, Benazzo and Andorno (2010: II 5 ) found evidence for $\mathrm{LI}$ influence in both learner groups. In particular, speakers of German produced more additive particles and speakers of French more similarity markings than a native Italian control group (Benazzo \& Andorno, 2010: I03). We therefore hypothesize that in particular less proficient French learners of German (level B) will produce a higher amount of similarity markings than the native German control group. We expect learners to come closer to target language frequency with advanced proficiency.

\subsection{Syntactic integration of additive particles}

As shown in the introduction, the target system differs from the learners' Li not only in the type and frequency of lexical expressions, but also in the way in which additive particles are syntactically integrated.

In the literature on German additive particles (Reis \& Rosengren, 1997; Krifka, 1999; Féry, 2012), explicit comparisons between two variants of auch are discussed, as shown in [Iza-b] from Féry (20I2).

5. Dimroth and Benazzo (accepted) show that the frequency difference is manifest in Li acquisition already at age 4. See also Fabricius-Hansen (2005) for similar observations concerning additive particles such as wieder, in German, English, and Norwegian. 
[iza] Auch [Maria $]_{\mathrm{FOC}}$ hat Kuchen gegessen. = pre-posed auch Also Maria has cake eaten.

'Maria also ate cake.'

[I2b] [Maria $]_{\text {TOP }}$ hat $\mathrm{AUCH}_{\mathrm{FOC}}$ Kuchen gegessen. = post-posed auch

Maria has also cake eaten.

'Maria ate cake, too.'

The two variants differ systematically with respect to the particle's position and its prosodic features. According to Reis and Rosengren's (1997) analysis, auch adjoins to all sorts of maximal projections ${ }^{6}$. If the particle precedes its co-constituent as in [12a] the co-constituent contains new information and carries the utterance's focal accent. If the particle follows the added information as in [I2b] the co-constituent contains given (and therefore de-accented) information and the particle is stressed ${ }^{7}$.

Krifka (1999), Dimroth (2004) and Féry (2012) assume that pre-posed auch (as in [I2a]) behaves like a typical focus particle, i.e., it associates with a constituent bearing focal stress (Féry, 20I2) that is interpreted as being added to contextually relevant alternatives. The added constituent of stressed and postponed auch [12b], on the other hand, is analyzed as a contrastive topic (Krifka, 1999; Dimroth, 2004; Sæbø, 2004) or even an ordinary topic (Féry, 2012). The focal accent of the relevant utterances is carried by the particle auch itself. In some accounts (Féry, 20I2), this is treated as a default landing site for a focal accent that must be placed somewhere, while others (Krifka, 1999; Dimroth, 2004) maintain that a focal accent on auch makes a semantic contribution that comes close to the meaning of "Verum Focus" (Höhle, 1992): focusing auch means focusing the utterance's assertive value in order to highlight that a particular predicative content does indeed hold for the topic under discussion. This is why we call the meaning contribution of post-posed particles exemplified in [12b] "assertion-based" whereas the meaning contribution of the pre-posed variant in [I2a] is called "entity-based". [I2b] answers an implicit polar question whereas [12a] answers an implicit Wh-question.

The situation is not so obvious for French where no stressed/unstressed dichotomy helps to distinguish different ways of integrating aussi and where more positions are possible; see the examples in [13] and Table $\mathrm{I}$ in the Introduction.

[ıза] Marie aussi a mangé du gâteau.

Marie also has eaten cake.

[13b] Marie a aussi mangé du gâteau. Marie has also eaten cake.

6. Alternative syntactic accounts treat auch as an adverbial. See Sudhoff (2008) for an overview of the advantages and disadvantages of the two accounts.

7. Reis and Rosengren (1997) maintain that the identification of Maria as added constituent in [12] is but an epiphenomenon of context embedding. According to their analysis, additive particles always affect the material in their syntactic scope, i.e., what is added in [I $2 \mathrm{~b}]$ is another token of a cake-eating event. 
[13c] Marie a mangé du gâteau aussi.

Marie has eaten cake also.

'Marie ate cake too.'

In [13a] aussi unambiguously identifies the preceding subject NP as the added constituent. Note that for the expression of an entity-based addition aussi must follow the subject, whereas auch, in the comparable structure in [12a] must precede it. $\left[\mathrm{I}_{3} \mathrm{~b}\right]$ has exactly the same word order as its German equivalent in [I2b]; the post-finite position is thus the only shared one and will in the following be interpreted as relating to the assertive value in French as well. In utterance final position as in [13c] aussi is ambiguous. This is also the case for elliptical utterances (Marie aussi) because it is unclear if the underlying full form is [13a], [ $\left.\mathrm{I}_{3} \mathrm{~b}\right]$, or [ $[\mathrm{I} 3 \mathrm{c}]$. The corresponding German variant (Maria auch), on the contrary, is clearly an elliptical form of [I2b] because auch precedes the added constituent in [I2a] and it is only the surface order that counts ${ }^{8}$.

Cross-linguistic comparisons of French and German utterances that were produced in reaction to the same elicitation stimuli (Dimroth et al., 20Iо; Benazzo \& Dimroth, 20I5) indicate that speakers of French prefer to use aussi as in [13a], whereas speakers of German prefer to use auch as in [I2b]. Even though the assertion-based post-posed variant of auch is clearly preferred in spoken German, around one third of the occurrences attested in the studies cited above correspond to the entity-based pre-posed variant of auch. Matching the target in L2 acquisition is thus a matter of preferences.

If learners look for similarities as suggested by Ringbom and Jarvis (2009), they should overexploit the only position available in both languages (cf. the grey cells in Table $\mathrm{I}$ in the Introduction). This also corresponds to the solution adopted during bilingual Li acquisition. Children acquiring German and French simultaneously (Leray, 2009; see also Hulk, 2003, for similar findings in Dutch/French bilinguals) do not transfer any of the "French only" positions onto German, but overuse the only shared position (Table I) when speaking French.

In a study of adult L2 learners of Italian with LI German, Benazzo and Andorno (20IO) show that the only target-like position preceding the added NP (anche X) is rapidly acquired. This position is comparable to the pre-posed position that is dispreferred but possible in German (auch X); the German post-posed position is not transferred onto Italian, which is to be expected if learners look for cross-linguistic similarities.

\section{Research questions}

Do L2 learners of German with Li French learn that in order to mark the subject as added constituent, the post-posed variant of auch is preferred over the pre-posed one? Do they also use the pre-posed position? Is one of the "French only" positions transferred onto German? Does learner behavior change with increasing overall proficiency?

8. Due to the strict $V_{2}$ rule, focused finite verbs are an exception. 
Given the preference for an entity-based integration of aussi in French we might expect that L2 learners of German would seek an unambiguously entity-related position and consequently overuse the pre-posed position (aucb NP). The less advanced learners might also transfer the corresponding French post-NP variant $\left({ }^{*} \mathrm{NP}\right.$ auch $\left.\mathrm{V}\right)$ for an entity-based linking. On the basis of the results from bilingual LI acquisition (Leray, 2009; Hulk, 2003), however, we rather expect that learners will overuse the post-posed position, i.e., the only position that auch and aussi share and that is both particularly frequent and also salient in the German input since auch in this position carries focal stress.

\subsection{Additive linking and discourse organization}

When confronted with the task of selecting components of their utterances that can be linked to preceding information units, speakers of French and German differ in their preferences (Dimroth et al., 20I0; Benazzo \& Dimroth, 2015). In a narrative discourse, in which particular events or situations are claimed to happen to entities (protagonists) over time, speakers of French tend to highlight the relation between different entities and prefer to use additive, but also contrastive expressions accordingly. Alternatively, they explicitly express the similarity of the relevant predicates (similarity marking). When deviating from the original narrative quaestio (What happened then to $X$ ?) speakers of French thus opt for one of the two Wh-questions (Who (else) did $X$ ? or What did $X$ do?). In a context like "Mr Green is sleeping" the corresponding utterances can have a form like $M$. Rouge, lui aussi, il dort, or M. Rouge fait la même chose, respectively.

The preferred strategy for establishing additive discourse relations in German, on the other hand, goes hand in hand with the assertion-based orientation of the language (Herr Rot geht AUCH scblafen) ${ }^{9}$. Discourse is thus locally organized as a response to an implicit polar question. For a French L2 learner of German this implies a considerable amount of re-organization on the basis of an input that is - again - characterized by preferences rather than categorical partitions.

There is ample evidence showing that even advanced L2 learners have a hard time overcoming the subtle preferences for information organization that are characteristic of their Li (cf. von Stutterheim, 2003; Lambert et al., 2008, for spatial and temporal information; Bohnacker \& Rosén, 2008, for the impact of information structure on word order; Ahrenholz, 2005; Leclercq \& Lenart, 2013 , for referring expressions). The picture emerging from studies addressing the $\mathrm{L}_{2}$ acquisition of additive and contrastive linking of information units in discourse (Benazzo \& Andorno, 20I0; Benazzo et al., 20I2; Tomita, 2013) is rather mixed. We will consider the findings in more detail here, since the three studies are based

9. Like the entity-based orientation of French, the assertion-based orientation of German does not only affect additive markings, but also shows up very clearly in contrastive contexts (Dimroth et al., 20Io; Benazzo et al., 2012; Turco et al., 2013). 
on data elicited with the same stimulus ("The Finite Story") as the current one and their findings are therefore particularly relevant for our study.

Benazzo and Andorno (2010) investigated the acquisition of additive linking in learners of Italian as a second language with $\mathrm{L}_{\mathrm{I}}$ French or German. The authors showed that native speakers of Italian resembled native speakers of French in their preferences for marking links between current entities and context entities, rather than links between assertions. For advanced German learners of Italian the study found that they did not fully adhere to the "Romance way" since they did not rely on similarity marking as frequently as native speakers of Italian. Overall, then, there seems to be moderate LI influence on the level of discourse organization, but not on the level of utterance grammar.

Benazzo et al. (2012) studied repercussions of the "Romance" vs. the "Germanic way" in the expression of contrastive (not additive) relations between discourse units by German learners of French or Italian and found the opposite picture: the learners had no difficulties in homing in on the entity-based information flow for contrast marking - the formal properties of their contrast markings, however, are not always target-like. The authors suggest that the lack of relevant lexical material in the input discouraged the learners from expressing contrastive information according to the Germanic way ${ }^{10}$. At the same time, the target grammatical devices for the expression of entity contrast (e.g., the contrastive pronoun lui in French) are only gradually acquired.

Tomita (2013) studied German learners of Japanese as L2 and found that learners' discourse organization was not fully target adequate. The difficulties, however, affected additive marking less than other traits of discourse organization. Like Italian and French, Japanese is shown to have a preference for marking links between alternative entities, rather than assertions. Results showed that German students of Japanese have a linking pattern very similar to that of the native speakers. The learners explicitly marked shifts between entities and used the additive particle -mo with almost target-like frequency.

In sum, these studies seem to suggest that a switch from an assertion-based to an entity-based preference for discourse organization is relatively easy. The fact that the learners did not attempt to transfer an assertion-based organization might, however, simply be due to the absence of the corresponding means in the input (no assertion-based position for anche in Italian; no assertion contrast markers in Italian and French).

Since entity-based solutions - though dispreferred - also exist in German (cf. example [4a] above) corresponding solutions are acquired with relative ease. If anything, it is rather the "Romance tendency" for similarity marking that is

10. Note, however, that studies focusing on prosody in a more controlled context did find transfer of the German "Verum Focus" intonation in German L2 learners of Italian; cf. Turco et al., 20I5. 
dismissed by learners with Li German. In the current study we are dealing with reorganization in the opposite direction - from the "Romance way" towards the "Germanic preference" for an assertion-centered organization.

\section{Research questions}

Do L2 learners of German with Li French reorganize their discourse in accordance with an assertion-based perspective? Does their behavior change with overall proficiency?

Most of the studies mentioned above suggest that reorganization of discourse structure is a long-lasting and difficult task for L2 learners. LI influence occurs unless the learners do not find any means that would allow the transfer of discourse principles (cf. Andersen's (1983) transfer to somewhere principle). This, however, is not the case for the current $\mathrm{L}_{\mathrm{I}} \mathrm{L}_{2}$ combination: French learners of German might well stick to an entity-based organization since evidence for this possibility is available in the German input. They might also transfer the French preference for similarity marking. Even though this solution occurred only very rarely in native speakers of German (Dimroth et al., 2010), it is of course possible to find translation equivalents of do the same. We therefore expect rather more $\mathrm{LI}_{\mathrm{i}}$ influence here than was found in German learners of Romance languages and Japanese.

\section{The study}

\subsection{Methods}

\subsubsection{Participants}

Data from two groups of adult native speakers of French $(\mathrm{N}=20)$ and German $(\mathrm{N}=40)$ were used as a control. The French data and part of the German data (20 speakers) were taken from the corpus collected for the study by Dimroth et al. (20IO); data from an additional group of 20 German speakers were added later with the aim of carrying out a phonological analysis. For the present analysis, however, intonation is not taken into account (see information on transcription and coding below).

Learner data were collected from intermediate $(\mathrm{N}=20)$ and advanced learners $(\mathrm{N}=20)$ of German with LI French ${ }^{11}$. All L2 participants grew up in a monolingual French speaking environment and began to learn the target language in a formal environment (school and/or high school) between the ages of 9 and 23 years. At the time of testing all learners had been living in Germany for at least two months (mostly in the context of an Erasmus student exchange). A standardized placement test ${ }^{12}$ was used to assess their level of proficiency in German. The test measures

11. We wish to thank Sarah Schimke who collected some of the learner data and made them available to us.

12. See: http://www.goethe.de/cgi-bin/einstufungstest/einstufungstest.pl. 


\begin{tabular}{|l|l|l|l|}
\hline Group & $\begin{array}{l}\text { Age at time } \\
\text { of testing }\end{array}$ & Education level & $\begin{array}{l}\text { Current staying time } \\
\text { in target country (learners only) }\end{array}$ \\
\hline $\begin{array}{l}\text { German natives } \\
(\mathrm{N}=40)\end{array}$ & $\begin{array}{l}20-45 \\
(\text { mean: } 30)\end{array}$ & $\begin{array}{l}\text { University degree } \\
\text { or students }\end{array}$ & - \\
\hline $\begin{array}{l}\text { French natives } \\
(\mathrm{N}=20)\end{array}$ & $\begin{array}{l}\text { I9-54 } \\
(\text { mean: } 28)\end{array}$ & $\begin{array}{l}\text { University degree } \\
\text { or students }\end{array}$ & - \\
\hline $\begin{array}{l}\text { B-learners } \\
(\mathrm{N}=20)\end{array}$ & $\begin{array}{l}\text { I9-29 } \\
(\text { mean: } 23.6)\end{array}$ & $\begin{array}{l}\text { University degree } \\
\text { or students }\end{array}$ & $\begin{array}{l}\text { 2 months-3 years } \\
\text { (average: } 8.8 \text { months) }\end{array}$ \\
\hline $\begin{array}{l}\text { C-learners } \\
(\mathrm{N}=20)\end{array}$ & $\begin{array}{l}\text { I9-43 } \\
(\text { mean: } 22.6)\end{array}$ & $\begin{array}{l}\text { University degree } \\
\text { or students }\end{array}$ & $\begin{array}{l}\text { 4 months-2 years } \\
\text { (average: } \text { II.I months) }\end{array}$ \\
\hline
\end{tabular}

Table 2. Participants

competences in reading, grammar, and vocabulary. Proficiency scores were used to assign learners to the levels proposed by the CEFRL. The intermediate learners' test performance corresponds to the $\mathrm{B}_{\mathrm{I}} / \mathrm{B}_{2}$ levels (henceforth "B-learners"); the advanced learners' performance corresponds to the $\mathrm{CI}_{\mathrm{I}} / \mathrm{C}_{2}$ levels (henceforth "C-learners") ${ }^{13}$. The main biographical characteristics of the participants are summarized in Table 2.

\subsubsection{Materials}

The oral data consist of retellings of "The Finite Story" ${ }^{14}$. The stimulus consists of $3 \mathrm{I}$ animated video clips (lasting between 4 and 22 seconds). Like a picture story, the segments show individual events and situations. Together they add up to a story about a near catastrophe. The video clips show three protagonist entities (Mr Blue, Mr Red and Mr Green) who live in a big house that catches fire one night. Until they are finally rescued by the fire brigade the protagonists are mostly shown individually during the performance of similar or opposite actions (sleeping or not sleeping; jumping or not jumping into a rescue net). The stimulus thus contains a high number of similar (but not equal) situations, making the expression of additive and contrastive links between the relevant information units likely. For the current study we selected all additive scenarios with an immediately preceding antecedent in which the same situation applied to a different discourse entity (cf. Table 3).

\subsubsection{Procedure}

An experimenter played the video segments one-by-one on a computer screen that could be seen by both the experimenter and the participant. The experimenter used the first two film segments to familiarize the participants with the protagonists and their living places. The participants were then informed that they were going to

13. Only three out of the 20 most advanced learners actually had $\mathrm{C}_{2}$ scores.

14. The stimulus is available at: https://www.iris-database.org/iris/app/home/index. 


\begin{tabular}{|l|l|l|}
\hline \multirow{2}{*}{ Number } & Content of context and additive segment (bold) & $\begin{array}{l}\text { Position of segment } \\
\text { in original sequence }\end{array}$ \\
\hline \multirow{2}{*}{2} & Mr Blue going to bed & segment 3 \\
\cline { 2 - 3 } & Mr Green going to bed & segment 4 \\
\hline \multirow{3}{*}{3} & Mr Green going to bed & segment 4 \\
\cline { 2 - 4 } & Mr Red going to bed & segment 5 \\
\hline \multirow{3}{*}{4} & Mr Green sleeping despite fire on roof & segment 7 \\
\cline { 2 - 4 } & Mr Red sleeping despite fire on roof & segment 8 \\
\hline \multirow{3}{*}{5} & Mr Green waking up, worrying & segment 20 \\
\cline { 2 - 4 } & Mr Red waking up, worrying & segment 2I \\
\hline \multirow{2}{*}{6} & Mr Green refusing to jump into rescue net & segment 24 \\
\cline { 2 - 4 } & Mr Red refusing to jump into rescue net & segment 25 \\
\cline { 2 - 4 } & Mr Blue jumping into rescue net & segment 26 \\
\cline { 2 - 4 } & Mr Green jumping into rescue net & segment 27 \\
\hline
\end{tabular}

Table 3. Selected "Finite Story" video segments

see several scenes showing the events of a dramatic evening and they were explicitly asked to retell "What happened to Mr Red, Mr Green and Mr Blue on that evening" immediately after each segment.

The resulting retellings were recorded with an audio recorder. Li speakers of French were recorded in France; Lr and L2 speakers of German were recorded in Germany. To avoid possible code-switching with the LI, the two experimenters - each one recorded a part of the participants - were native speakers of German. They had the role of rather passive listeners and intervened only when necessary (e.g., when a participant asked for a word).

\subsubsection{Transcription and coding}

The data were transcribed orthographically with the program ELAN. Prosodic details such as the accent on the particle aucb or on potentially contrastive NPs or pronouns were noted but finally not taken in consideration because frequent hesitations, false starts, and self-corrections in the learner data made their interpretation too ambiguous.

For our main analysis, we selected the responses to 6 additive stimuli (video segments) per speaker, i.e., a total of I2O contexts for native speakers of French and both learner groups $(\mathrm{N}=20)$ and 240 contexts for native speakers of German $(\mathrm{N}=40)$. Occasionally speakers misunderstood the scenes. If their interpretation did not license the use of additive markings, the responses were discarded from further analysis (see "Number of contexts considered" in Table 5 below). 
The relevant responses were coded with respect to the following criteria: presence (yes/no) and type of additive expression (additive particle/additive adverbial [ebenfalls, également]/similarity marking [variants of do the same]). Note that French aussi is rendered as non plus under negation. The category "additive particle" therefore includes aussi and non plus for French and auch for German.

Utterances containing additive particles were coded for the type of added constituent (subject/non-subject). In order to ensure maximum comparability, only subject-cases were included in the syntactic analysis and coded for type of syntactic integration (entity-based/assertion-based/ambiguous). The category "entity-based" included additive particles directly preceding the subject in German and additive particles in a position between the subject and the finite verb in French (the latter position is ungrammatical in German but was sometimes used by $\mathrm{L}_{2}$ speakers). Additive particles following strong pronouns (lui) were always coded as entity-based.

The category "assertion-based" included additive particles in a post-finite position in German and French. In French, the relevant particles are always right-adjacent to the finite verb. In German, other constituents (including the subject, due to inversion) can intervene. As long as the particle follows the subject, even elliptical utterances can be classified as assertion-based (entity-based elliptical constructions did not occur). The category "ambiguous" was needed for French where it comprises all additive particles in final position and elliptical utterances (Paul aussi) that can, in principle, be derived from an entity-based or an assertion-based construction. When L2 learners produced German auch in final position, the relevant utterances were also coded as "ambiguous". Table 4 illustrates the relevant categories with examples from both languages.

For the analysis of discourse organization, additional data from the retellings were added (see Section 3.2.3 for details).

\begin{tabular}{|l|l|l|}
\hline Entity-based & $\begin{array}{l}\text { German (Li and L2) } \\
\text { auch Paul geht ins bett } \\
\text { dann geht auch Paul ins bett } \\
\text { *Paul auch gebt ins bett (only L2) }\end{array}$ & $\begin{array}{l}\text { Paul aussi (il) va se coucher } \\
\text { Paul va se coucher lui aussi }\end{array}$ \\
\hline Assertion-based & $\begin{array}{l}\text { Paul geht auch ins bett } \\
\text { dann geht Paul auch ins bett } \\
\text { Paul auch }\end{array}$ & Paul va aussi se coucher \\
\hline Ambiguous & *Paul geht ins Bett auch (only L2) & $\begin{array}{l}\text { Paul va se coucher aussi } \\
\text { Paul aussi }\end{array}$ \\
\hline
\end{tabular}

Table 4. Coding categories and examples concerning the position of additive particles in relation to the subject as added constituent 


\subsection{Results}

\subsubsection{Additive linking}

Table 5 reports absolute numbers for the core additive particles (aucb/aussi/non plus) as well as for the other additive linking devices attested in the data ${ }^{15}$. As speakers from all groups sometimes produced responses containing more than one type of marking (cf. example [I4] below), the "total" of marked and unmarked expressions can be higher than the number of stimuli (video segments) analyzed (rightmost column in Table 5 ).

[I4] ganz gleich für rote Figur; er ist ängstlich auch (B-learner) entirely similar for red figure; he is afraid too

With respect to the frequency of the core additive particles in source and target language, Table 5 clearly confirms earlier findings in that German auch (172/236) occurs at least twice as often as French aussi (40/II7) - despite the fact that only adjacent segments were considered. A Kruskal-Wallis $\mathrm{H}$ test showed that there was a significant difference in the use of additive particles between the two native groups $\left(\chi^{2}(\mathrm{I})=25.669 ; p<0.00 \mathrm{I}\right)^{16}$. Again in accordance with earlier findings, native speakers of French rely more heavily on similarity markings of the type faire la même chose $\left(\chi^{2}(\mathrm{I})=19.273 ; p<0.00 \mathrm{I}\right.$; see example [I5] below). The difference concerning the frequency of additive adverbials by native speakers of French and German is not significant $(p>0.05)$. There is overall more variation in Li French than in Li German, but there are also more responses in French that are not explicitly marked for addition in any way $\left(\chi^{2}(\mathrm{I})=7 . \mathrm{II} ; p<0.05\right)$.

\begin{tabular}{|l|c|c|c|c|c|}
\hline & $\begin{array}{l}\text { Additive } \\
\text { particle }\end{array}$ & $\begin{array}{l}\text { Additive } \\
\text { adverbial }\end{array}$ & $\begin{array}{l}\text { Similarity } \\
\text { marking }\end{array}$ & $\begin{array}{l}\text { No additive } \\
\text { expression }\end{array}$ & $\begin{array}{l}\text { Number } \\
\text { of contexts } \\
\text { considered }\end{array}$ \\
\hline LI French & 40 & I3 & 23 & 44 & II7 \\
\hline $\begin{array}{l}\text { L2 German } \\
\text { B-learners }\end{array}$ & 78 & 2 & 24 & 20 & II9 \\
\hline $\begin{array}{l}\text { L2 German } \\
\text { C-learners }\end{array}$ & 96 & 0 & 8 & I7 & II7 \\
\hline LI German & I72 & I4 & 7 & 48 & 236 \\
\hline
\end{tabular}

Table 5. Types of additive expressions

15. A table with the means per participant can be found in the appendix.

16. We wish to thank Alina Matei for her statistical advice concerning the analyses of questions I and 2. 
Four observations can be made with respect to the second language learners. I) Both learner groups use auch with target-like frequency. Neither the differences between learners at level B and native speakers of German $(p>0 . \mathrm{I})$ nor the differences between learners at level $\mathrm{C}$ and native speakers of German $(p>0 . \mathrm{I})$ are significant. However, learners at level C use aucb significantly more often than learners at level B $\left.\left(\chi^{2}(\mathrm{I})=5.934 ; p<0.05\right) .2\right)$ At proficiency level B, similarity markings (see examples [I5] and [16] below) appear as often as in $\mathrm{LI}\left(\chi^{2}(\mathrm{I})=0.095 ; p>0.05\right)$ whereas their frequency drops at proficiency level C. Level C learners produced as few similarity markings as German Li speakers $\left(\chi^{2}(\mathrm{I})=2.007 ; p>0.05\right)$ and thus, less than French LI $\left.\left(\chi^{2}(\mathrm{I})=6.66 ; p<0.05\right) .3\right)$ In the entire learner corpus there are only two occurrences of additive adverbials (produced by the same B-learner). 4) With regard to the unmarked utterances, the learners are also closer to the native speakers of German than to the native speakers of French. There is neither a statistical difference between B-learners and German Li speakers $(p>0.05)$ nor between C-learners and German Li speakers $(p>0.05)$, but French Li speakers leave significantly more utterances unmarked than B-learners $\left(\chi^{2}(\mathrm{I})=8.234 ; p<0.05\right)$ and C-learners $\left(\chi^{2}(\mathrm{I})=9.68 \mathrm{I} ; p<0.05\right)$.

[is] M. Rouge est dans le même état (Li French)

$\mathrm{Mr}$ Red is in the same condition

[16] der Grüne macht genau dasselbe (B-learner)

the green-one does exactly the-same

Answers to research questions (i):

additive particles vs. other lexical devices for additive linking

Do L2 learners of German with Li French match the frequency of additive particles displayed by native speakers of German? Yes, the frequency of additive particles ( $a u c h)$ in the learner groups does not differ from that of native speakers of German.

Do they use other markings, and if so, are these similar to the ones used by native speakers of French? In accordance with native French, the intermediate learner group produces more similarity markings than native speakers of German. Additive adverbials appear only very rarely in both learner groups.

Does the learner behavior change with increasing overall proficiency? Yes, in comparison to level B there seems to be less LI-influence at level C (cf. the decrease in similarity markings and the increase in additive particles). Overall the level C learners show less variation and rather overshoot the mark for the preferred target language solution.

\subsubsection{Syntactic integration}

In order to find out which type of syntactic integration was produced by the different speaker groups we selected a sub-corpus of comparable utterances. This corpus contains all main clauses containing occurrences of aussi/non plus/auch with the grammatical subject as added constituent ( $62 \%$ of the corpus analyzed in the preceding section). 
For Li German, all occurrences of additive particles can be unambiguously classified as preceding the subject (entity-based integration) or following the subject (assertion-based integration). For French we distinguished between particles occurring right-adjacent to the subject (entity-based integration), post-finite particles (assertion-based integration), and utterance final particles (ambiguous).

Figure I shows the proportions of the different possibilities relative to the sum of additive particles in the sub-corpus. The category "entity-based" includes the German pre-posed position "aucb S" and the French right-adjacent position "S aussi V" as well as learner realizations of the type "S auch V" that are ungrammatical in German. The category "assertion-based" comprises post-posed particles in post-finite position (this is the position shared by both languages). The category "ambiguous" contains particles in final position that cannot be assigned to either of the other two categories. Details on the categories can be found in Table 4 above.

Concerning the preferred placement of the additive particles in native speakers of French and German the results again confirm earlier findings. Kruskal-Wallis $\mathrm{H}$ tests were conducted to determine whether the proportion of the three different kinds of syntactic integration for the two native groups was different. There is a significant difference for the assertion-based position $\left(\chi^{2}(\mathrm{I})=52.32, p<0.00 \mathrm{I}\right)$ that is preferred in German and dispreferred in French as well as for the final position $\left(\chi^{2}(\mathrm{I})=\mathrm{I} 25.4 \mathrm{I}\right.$, $p<0.00 \mathrm{I})$ because there were no ambiguous utterances in German natives. Utterances with the additive particle adjacent to the affected subject NP (i.e., in an entity-based position) appear with equal frequency in both native groups $(p>0.05)$.

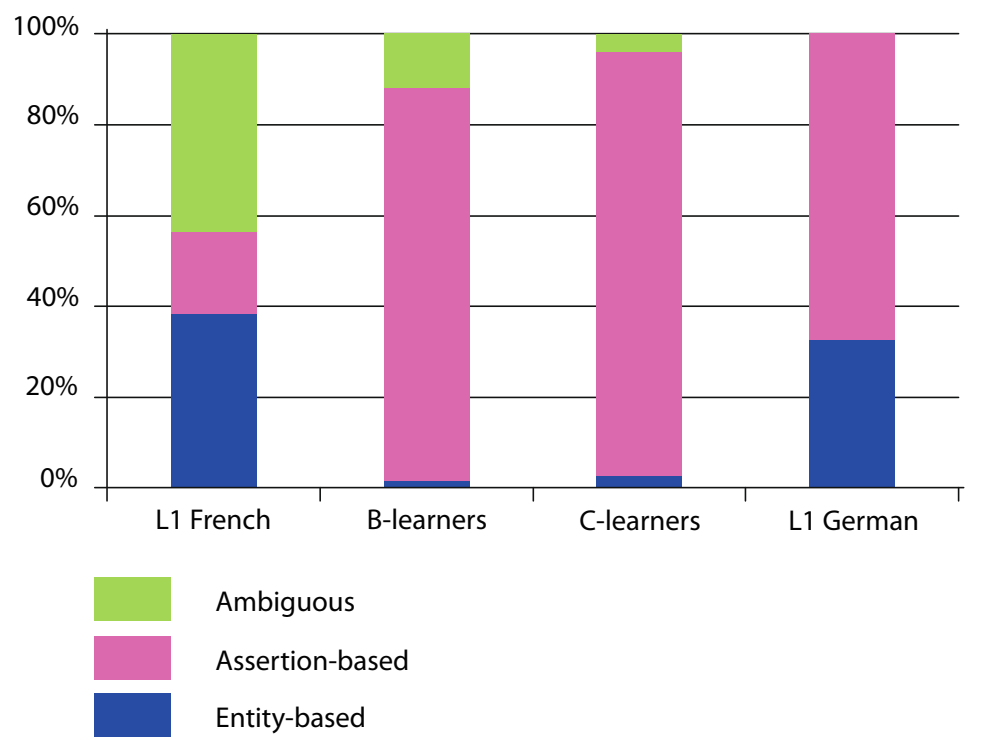

Figure 1. Relative frequency of integration categories (out of all occurrences in the sub-corpus) 
The following three observations can be made with respect to the learner data. I) There is some transfer (mainly at level B) of "French only" positions onto German (cf. the ungrammatical examples [17a] and [17b] below). Nevertheless, even at level B learners choose the "French only" positions statistically less often than French natives $\left.\left(\chi^{2}(\mathrm{I})=23.72, p<0.00 \mathrm{I}\right) .2\right)$ Learners largely ignore the pre-posed variant left-adjacent to the subject NP. This "German-only" position is not used at level B (but see example [17a] for a transfer variant of an entity-based integration), and occurs only twice at level C. 3) Both learner groups use the shared assertion-based position with the same frequency (level B: $89 \%$; level C: $94 \% ; p>0.05)$. In both groups, the frequency of this position is higher than in the German native speakers (level B: $\chi^{2}(\mathrm{I})=30.56, p<0.00 \mathrm{I}$; level C: $\chi^{2}(\mathrm{I})=47.65$, $p<0.00 \mathrm{I})$.

[17a] Herr Rot auch hat zu Angst um zu springen (B-learner) $\mathrm{Mr}$ Red also is too frightened in-order to jump

[I7b] dann ist er gesprungen auch (C-learner) then has he jumped too

\section{Answers to research questions (ii): syntactic integration}

Do L2 learners of German with Li French learn that in order to mark the subject as added constituent, the post-posed variant of auch is preferred over the pre-posed one? Yes, in fact they use this position nearly exclusively.

Do they also use the pre-posed position? No, the German variant of an entitybased integration of auch occurred only twice at level C.

Is one of the "French only" positions transferred onto German? Auch occurs only sporadically in an ungrammatical position.

Does learner behavior change with increasing overall proficiency? There is no clear answer to this question. On the one hand, the transfer of the "French-only" final position that was already rarely used at level B is reduced even further at level C. On the other hand, the shared assertion-based position is overused even more at level C. For both possibilities of syntactic integration, there are no significant differences between the two learner groups $(p<0.05)$. Crucially, however, there is practically no development with respect to the pre-posed position.

Both level B and level C learners use the post-posed position in nearly all cases, i.e., the learners overexploit the only position for additive particles that French and German share, whereas they ignore the possibility of an entity-based integration altogether. If this is due to a transfer of structures that the learners find similar, we must conclude that it is similarity on the form side, not on the function side that counts. In the last results section we address the question of whether the assertionbased position for auch adopted by the learners corresponds to an assertion-based discourse organization. 


\subsubsection{Discourse organization}

Analysis I aims at finding out whether French learners of German use more structures indicative of an entity-based discourse organization than the native speakers. Table 6 lists all expressions occurring in the retellings (i.e., also outside the additive utterances) that highlight the fact that there are alternatives to the entity currently talked about. Four types of markings were considered: I) leftdislocation of NPs followed by contrastive pronouns; 2) presentational structures mostly followed by a relative clause hosting the principal information; 3) lexical expressions of contrast between entities (French: par contre, de son côté, à son tour; German: bingegen, seinerseits, nur); 4) demonstrative pronouns. Examples from native speakers of both languages are given in [I8]. Table 6 lists absolute frequencies for these expressions.

[r8a] M. Bleu lui il saute par la fenêtre Mr Blue him he jumps out of the window

Herr Blau der legt sich hin und schläft

Mr Blue he lies down and sleeps 
[18b] on voit $M$. Vert qui est réveillé et assis sur le lit one sees Mr Green who is awake and sitting on the bed

Herr Grün ist zu sehen der jetzt wach ist $\mathrm{Mr}$ Green can be seen who is now awake

[I8c] par contre M. Rouge ne veut toujours pas sauter on the other hand Mr Red still does not want to jump

Herr Rot hingegen weigert sich [...] hinunterzuspringen $\mathrm{Mr}$ Red on the other hand refuses to jump down

[I8d] celui-ci se décide à sauter this-one decides to jump

dieser überlegt nicht lange this-one does not hesitate for a long time

Taking into account the fact that there are 40 speakers of Li German it becomes evident that entity-contrast markers occurred nearly four times more often in LI French than in LI German. In particular left dislocation and the presentational structures were used with high frequency whereas they are nearly absent from the German Li corpus ${ }^{17}$. The most frequent markings in German were the demonstrative pronoun dieser and lexical markers, in particular nur ("only") that did not occur in French.

The L2 learners did not use the demonstrative pronoun dieser at all and did not differ from the native speakers with respect to the use of lexical devices. Presentationals and left-dislocations, however, occurred more frequently in the L2 than in the Li German data. For left dislocation, a potential transfer can be seen only at proficiency level $\mathrm{C}$ - maybe because the relevant syntactic structure is not in place earlier. Learner examples for the structures in [18] are given in [19] below.

\begin{tabular}{|l|c|c|c|c|c|}
\hline & $\begin{array}{l}\text { Left dislocation }+ \\
\text { contrastive pronoun }\end{array}$ & Presentational & $\begin{array}{c}\text { Lexical } \\
\text { devices }\end{array}$ & Demonstrative & Total \\
\hline Li French & 25 & I4 & 9 & 9 & 57 \\
\hline $\begin{array}{l}\text { L2 German } \\
\text { B-learners }\end{array}$ & I & I2 & 4 & 0 & I7 \\
\hline $\begin{array}{l}\text { L2 German } \\
\text { C-learners }\end{array}$ & 8 & I4 & 5 & 0 & 27 \\
\hline Li German & I & 7 & II & I4 & 33 \\
\hline
\end{tabular}

Table 6. Absolute frequencies of expressions contrasting the entity currently talked about with entities in the preceding context (entire retellings)

17. In the literature on information structure (cf. Klein, 20I2; Lambrecht, 1994) left dislocations and presentational structures are treated as typical properties of spoken French. 
[19a] der Herr Blau der springt (C-learner)

Mr Blue he jumps

[igb] wir können sehen den blaue Figur der ins Bett geht (B-learner) we can see the blue figure who goes to bed

[rgc] jetzt ist Herr Rot dran (C-learner) now it is Mr Red's turn

Figure 2 presents a comparison of the learners (both groups together, $\mathrm{N}=40$ ) with the native speakers of German $(\mathrm{N}=40)^{18}$. It shows that the overall frequency of entity-based contrasts is slightly higher in the L2 group (44 vs. 33 occurrences). Given, however, that the demonstrative pronoun that accounts for nearly half of the markings in Li German was completely lacking from the learner repertoire, it becomes clear that at least the two syntactic structures (left dislocation and presentationals) were heavily overused by the learners.

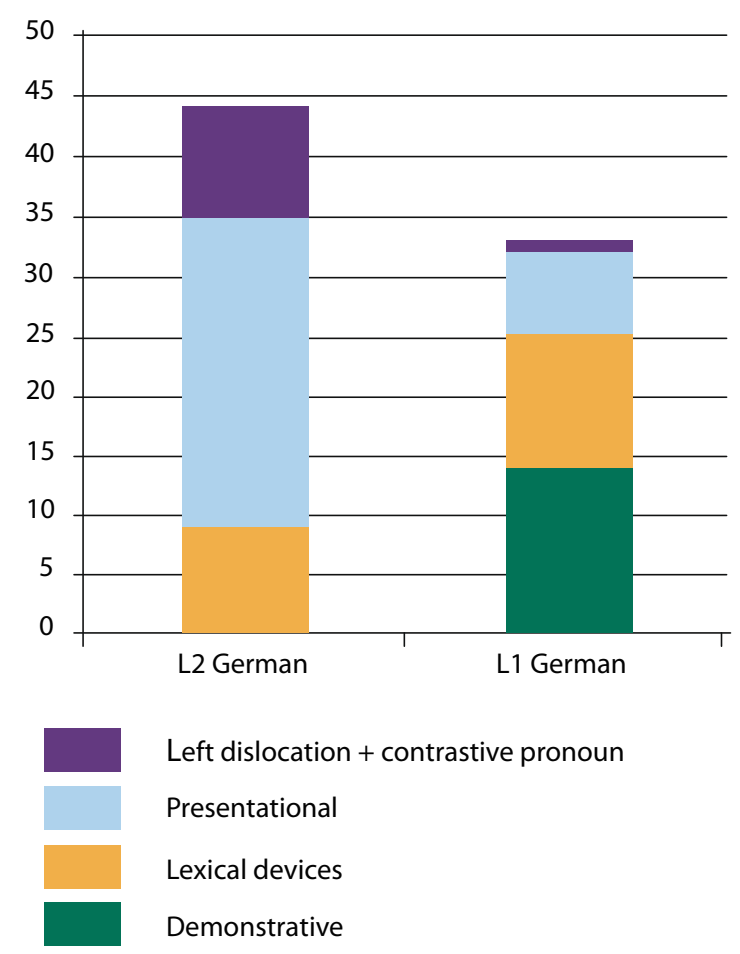

Figure 2. L2 learners vs. native speakers of German: frequency of expressions highlighting that there are alternatives to the entity currently talked about (absolute numbers)

18. Because of the exploratory character of this part of the analysis and the small frequency values of the relevant structures, no statistical test was done for this part. 


\begin{tabular}{|l|c|c|c|c|c|}
\hline & $\begin{array}{l}\text { Transition } \\
\text { marking }\end{array}$ & $\begin{array}{l}\text { Concessive } \\
\text { connector }\end{array}$ & $\begin{array}{l}\text { Assertive } \\
\text { particle }\end{array}$ & $\begin{array}{l}\text { Total of } \\
\text { markings }\end{array}$ & $\begin{array}{l}\text { No change } \\
\text { of polarity } \\
\text { expressed }\end{array}$ \\
\hline Li French & I2 & 5 & 0 & I7 & 6 \\
\hline $\begin{array}{l}\text { L2 German } \\
\text { B-learners }\end{array}$ & 7 & 0 & 0 & 7 & 13 \\
\hline $\begin{array}{l}\text { L2 German } \\
\text { C-learners }\end{array}$ & 6 & 3 & 3 & I2 & 9 \\
\hline Li German & I6 & 0 & 27 & 43 & 8 \\
\hline
\end{tabular}

Table 7. Absolute frequencies of markings in segment 29

(change of polarity between preceding and current segment)

Analysis 2 looks at one particular scene (segment 29), in which the subject entity is maintained from the immediately preceding scene, but the polarity changes from negation to affirmation: segment 28 shows one of the protagonists (Mr Red) at a window of the burning house. There are firemen with a rescue net below his window, but he does not want to jump out. This scene, in which a strongly expected event does not occur, elicited utterances containing negation or inherently negated predicates (refuse to, be too afraid to, etc.). The situation shown in segment 29 is similar, but this time the protagonist jumps out of the window. There are thus two information units that change, the time (encoded by a similarly high proportion of French and German speakers with adverbials like finally, in the end, etc.), and the polarity. We will focus on the latter in order to find out if the French learners of German have adopted the assertion-based perspective (i.e., the "Germanic way").

The following two options for signalling the change in polarity in German were considered. Speakers can either use the assertion-based affirmative particle doch ("indeed") ${ }^{19}$ or lexically modify the predicate with the help of verbs like convince, persuade, or change bis mind that presuppose a prior state in which the protagonist held a different opinion. This option will be called transition marking below. The two options can also be combined (see [20]). A third option attested in French as well as L2 German consists of concessive connectors (French: quand même, tout de même; German: trotzdem; "nevertheless", see [2I]). Table 7 reports absolute frequencies of each type of marking in the retellings of segment 29 only. As native speakers and learners at proficiency level $\mathrm{C}$ sometimes produced responses containing two options (cf. examples [20] and [2I]), the sum of the markings and the unmarked utterances for polarity change (the two rightmost columns in Table 7) can be higher than the number of stimuli (video segments; 20 or 40 per group) analyzed.

19. Due to the difficulties with an intonation analysis of free learner productions, another prominent expression in German, "Verum Focus" (i.e., a pitch accent on the finite verb), is not considered here. 
[20] nach einer kurzen Weil überzeugen die Feuerwehrmänner Herr Rot doch zu springen after a short while the firemen convince Mr Red to jump indeed.

[2I] finalement les pompiers l'ont persuadé de sauter quand même finally the firemen persuaded him to jump nevertheless

Whereas a chi-square test shows no difference for the use of transition marking in all four speaker groups $(p>0.05)$, it is different for the other two types of markings. Concessive connectors are used by native speakers of French in a quarter of all cases. As with the entity-based structure "left dislocation plus contrastive pronoun" discussed above, a potential transfer can only be seen at level C, likely because the necessary means are not yet available at the intermediate level B. Even more striking is the difference between native speakers and learners with respect to the assertive particles that were used with very low frequency by the learners $\left(\chi^{2}(2)=15.58, p<0.00 \mathrm{I}\right)$. Like the concessive connectors, all three occurrences were produced by level $\mathrm{C}$ learners. The examples in [22] illustrate the learner variants of the three marking options.

[22a] am Ende er entscheidet sich und geht durch die Fenster (transition marking; B-learner) at the end he decides and goes through the window

[22b] am Ende springt Herr Rot trotzdem vom Fenster (concessive connector; C-learner) at the end Mr Red jumps nevertheless from the window

[22c] so Herr Rot ist doch gesprungen (assertive particle; C-learner) so Mr Red jumped indeed

The difference between learners and native speakers of German can be seen more clearly in a direct comparison. Due to the possibility of double markings and the relatively high number of completely unmarked utterances in the sub-corpus of the learners, Figure 3 shows absolute numbers for both learner groups $(\mathrm{N}=40)$ as opposed to native speakers of German $(\mathrm{N}=40)$.

Taken together, Figures 2 and 3 indicate an overuse of syntactically complex structures highlighting across-utterance contrasts between entities (left dislocation, presentationals) and an underuse of comparably simple assertion-related means, like the particle doch, on the other hand. Lexical transition markers modifying the content (Now it's Mr Blue's turn; The firemen convinced Mr Red) are used with roughly equal frequency by native speakers and L2 learners of German. Tables 6 and 7 furthermore show that the transfer of some of the French-like structures (left dislocation, concessive connectors) increases at an advanced proficiency level.

Answers to research questions (iii): discourse organization

Do L2 learners of German with Li French reorganize their discourse in accordance with an assertion-based perspective? Overall, learners use slightly more entity-based 

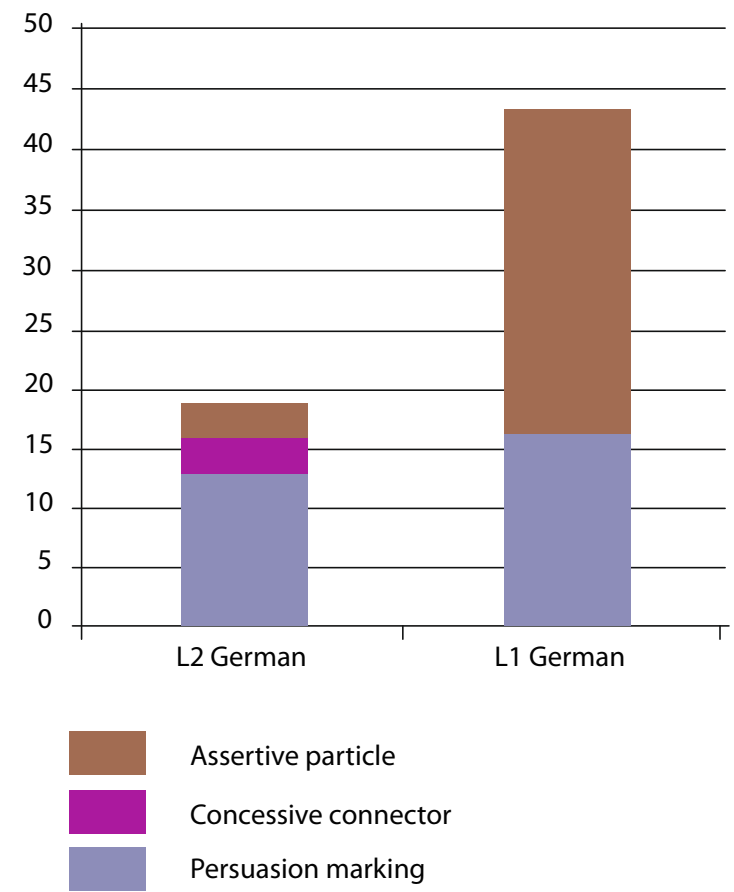

Figure 3. L2 learners vs. native speakers of German: absolute numbers of different types of expressions highlighting a change from negative to affirmative polarity (segment 29 only)

contrastive linkings than native speakers of German. The demonstrative pronoun dieser is, however, missing from their repertoire. Instead, cohesion across utterances is achieved through syntactic structures such as left dislocations and presentationals that highlight the role of the protagonists and have an information structure adapted to a subject Wh-question. On the other hand, learners produce hardly any assertion-based markings. A context eliciting contrastive affirmative particles (and thus utterances geared towards underlying polar questions) from native speakers of German was largely left unmarked.

Does the learners' behavior change with overall proficiency? Transfer of the more complex entity-based structures rather increases at level $\mathrm{C}$ when the necessary means are available. The only affirmative particles in the sub-corpus were also produced by level $\mathrm{C}$ learners.

\section{Discussion and conclusions}

In this paper, markers of additivity produced by French learners of German as a second language were studied as an example of a phenomenon where cross-linguistic differences but also similarities between source and target language become influential 
at different levels of linguistic organization. On the one hand, there are similarities and differences on the form side, i.e., concerning the lexical and the syntactic properties of the relevant expressions. On the other hand, there are similarities and differences concerning overall patterns for preferred discourse organization, i.e., the "Romance way" vs. the "Germanic way" of making a discourse coherent, when the content suggests local deviations from a default narrative discourse question or quaestio.

Our study has shown that even intermediate learners come close to the target with respect to lexical choice (core additive particle instead of adverbials or other types of similarity markings) and frequency of use. Concerning the syntactic integration, advanced learners rely almost exclusively on the post-posed position of additive particles that is also preferred by native speakers of German and overused in French by French-German bilingual children (Leray, 2009). This position is frequent and salient in the input. At the same time, it is the only shared position, even if other positions are used more frequently in French. Importantly, the post-posed position is associated with an assertion-based information organization in German where the relevant utterances can be read as answers to an underlying polar question. That this perspective is rather atypical for French does not prevent the learners from overusing the corresponding target position.

In fact the L2 learners did not even show serious attempts to find expressions corresponding to an entity-based discourse organization in their target language. The entity-based target pattern involves a "German-only" position of the additive particle (pre-posed to the added NP) that was used only very rarely by the more advanced learners. A transfer of the corresponding "French-only" position (post-posed to the added NP) did not systematically happen either. We can thus conclude that cross-linguistic similarities at the form level played an important role in shaping the learner system whereas no considerable attempt was made to exploit similarities on the discourse organizational level (an entity-based linking is typical for French and also occurs in the native German stories). We can thus subscribe to Benazzo et al. (2012: 198) who studied the acquisition of a Romance target language by learners with either a Germanic or another Romance source language and concluded: "Nos résultats confirment que les apprenants sont initialement plus à la recherche des similarités formelles entre $L_{\mathrm{I}} / L C$ que de différences et qu'ils ne vont pas forcément plus loin, une fois ces similarités constatées" 20.

With respect to the expression of additive relations, we can say that formal similarity wins over functional similarity and the result is a rather schematic learner system instantiating the most frequent target variant and ignoring all others. This is particularly clear for the most advanced learners who reduced the transfer of "French-only" positions without, however, acquiring the "German-only" ones.

20. "Our results confirm that, initially, learners look for formal similarities more than differences between source and target language and that they do not necessarily develop beyond the similarities they have identified" (authors' translation). 
From this uniform behavior, however, we cannot conclude that the learners adopted the target language's discourse organizational preferences with the same rigor. Instead, when looking at discourse structure beyond the additive utterances, we found evidence for the learner's maintenance of an entity-based organization. When the content of the retellings offered a possibility to highlight entities and to construe them as an alternative to other entities the learners - in accordance with their source language - seized the opportunity to do so. Here again this pattern is even stronger in the more advanced learners. At the same time, an assertion-based organization is largely ignored, even in contexts eliciting the relevant information structure from native speakers in a reliable way.

As predicted by Flecken et al. (2013; cf. Introduction), we are thus dealing with a hybrid system that involves source as well as target organizational principles. When challenged by the construction of a narrative with an unusual distribution of changed vs. maintained information, even advanced L2 learners rely rather heavily on the "transferable" patterns of discourse organization that so smoothly solve the problem in their source language. In the light of these results, it is unclear to what extent the learners' massive use of post-posed additive particles that are associated with an assertion-based information flow in the target language can really be taken at face value. This is a question for further research that can, however, not be solved on the basis of production data alone.

\section{References}

Ahrenholz, B. 2005. Reference to Persons and Objects in the Function of Subject in Learner Varieties. In H. Hendriks (ed.), The Structure of Learner Varieties. Berlin - New York: De Gruyter: 19-64.

Amsili, P. \& Beyssade, C. 20Io. Obligatory Presupposition in Discourse. In P. KüHnlein, A. Benz \& C.L. Sidner (eds.), Constraints in Discourse 2. Amsterdam - Philadelphia: J. Benjamins: I05-I24.

Andersen, R.W. 1983. Transfer to Somewhere. In S. Gass \& L. Selinker (eds.), Language Transfer in Language Learning. Rowley: Newbury House Publishers: 177-20I.

Andorno, C. 1999. Avverbi focalizzanti in italiano. Parametri per un'analisi. Studi Italiani di linguistica teoretica e applicata 28 (I): 43-83.

Benazzo, S. \& Andorno, C. 2oro. Discourse Cohesion and Topic Discontinuity in Native and Learner Production: Changing Topic Entities on Maintained Predicates. In L. Roberts, M. Howard, M. Ó Laoire \& D. Singleton (eds.), EUROSLA Yearbook. Amsterdam - Philadelphia: J. Benjamins. Vol. ıо: 92-II8.

Benazzo, S., Andorno, C., Interlandi, G. \& Patin, C. 20I2. Perspective discursive et influence translinguistique: exprimer le contraste d'entité en français et en italien L2. Language, Interaction and Acquisition 3 (2): 173-201.

Benazzo, S. \& Dimroth, C. 20I5. Additive Particles in Romance and Germanic Languages: Are They Really Similar? Linguistik Online 7I (2): 9-30. Available online: https://bop. unibe.ch/linguistik-online/article/download/I776/3006. 
Blumenthal, P. 1985. "Aussi” et "auch": deux faux amis? Französisch heute 2: 144-150.

Bohnacker, U. \& Rosén, C. 2008. The Clause-Initial Position in L2 German Declaratives: Transfer of Information Structure. Studies in Second Language Acquisition 30 (4): 5II-538.

Clifton, C. JR. \& Frazier, L. 20I2. Discourse Integration Guided by the "Question under Discussion”. Cognitive Psychology 65 (2): 352-379.

Diмroth, C. 2004. Fokuspartikeln und Informationsgliederung im Deutschen. Tübingen: Stauffenberg.

Dimroth, C., Andorno, C., Benazzo, S. \& Verhagen, J. 2oio. Given Claims about New Topics. How Romance and Germanic Speakers Link Changed and Maintained Information in Narrative Discourse. Journal of Pragmatics 42 (I2): 3328-3344.

Dimroth, C. \& Benazzo, S. (accepted). Developing Strategies for Encoding Additive and Contrastive Relations in French and German Child Narratives. In M. Garcia \& M. UTh (eds.), Focus Realization and Interpretation in Romance and Beyond. Amsterdam - Philadelphia: J. Benjamins.

Eckardt, R. \& Fränkel, M. 20I2. Particles, Maximize Presupposition and Discourse Management. Lingua I22 (I5): I8OI-I8I8.

Fabricius-Hansen, C. 2005. Elusive Connectives. A Case Study on the Explicitness Dimension of Discourse Coherence. Linguistics 43 (I): 17-48.

FÉRY, C. 20I2. Prosody and Information Structure of the German Particles "Selbst", "Wieder" and "Auch". In T. Borowsky, S. Kawahara, M. Sugahara \& T. Shinya (eds.), Prosody Matters: Essays in Honor of Elisabeth O. Selkirk. London: Equinox: 420-445.

Flecken, M., Stutterheim, C. von \& Carroll, M. 20I3. Principles of Information Organization in L2 Use: Complex Patterns of Conceptual Transfer. International Review of Applied Linguistics in Language Teaching - IRAL 5I (2): 229-242.

HöHLE, T.N. I992. Über Verum-Fokus im Deutschen. In J. JACOBS (ed.), Informationsstruktur und Grammatik. Opladen: Westdeutscher Verlag: II2-I4I.

Hulk, A. 2003. Merging Scope Particles. Word Order Variation and the Acquisition of "Aussi” and "Ook" in a Bilingual Context. In C. Dimroth \& M. Starren (eds.), Information Structure and the Dynamics of Language Acquisition. Amsterdam: J. Benjamins: 2II-234.

KLEIN, W. 20I2. The Information Structure of French. In M. KRIFKA \& R. Musan (eds.), The Expression of Information Structure. Berlin - Boston: De Gruyter: 95-I26.

KrifKa, M. I999. Additive Particles under Stress. In D. Strolovitch and A. Lawson (eds.), Proceedings of SALT 8. Ithaca: Cornell University: III-I28. Available online: http:// journals.linguisticsociety.org/proceedings/index.php/SALT/article/download/2799/2539.

Lambert, M., Carroll, M. \& Stutterheim, C. von 2008. Acquisition en L2 des principes d'organisation de récits spécifiques aux langues. Acquisition et interaction en langue étrangère - Aile 26: II-29. Available online: http://aile.revues.org/28I2.

LAmbrecht, K. 1994. Information Structure and Sentence Form: Topic, Focus, and the Mental Representations of Discourse Referents. Cambridge - New York: Cambridge University Press.

Leclerce, P. \& Lenart, E. 2013. Discourse Cohesion and Accessibility of Referents in Oral Narratives: A Comparison of LI and L2 Acquisition of French and English. Discours I2: I-3I. Available online: http://discours.revues.org/88oI. 
Leray, E. 2009. Additive Focus Particles in Bilingual Language Acquisition. In A. Dufter \& D. ЈАсов (eds.), Focus and Background in Romance Languages. Philadelphia: J. Benjamins: 205-238.

Reis, M. \& Rosengren, I. 1997. A Modular Approach to the Grammar of Additive Particles: The Case of German "Auch”. Journal of Semantics I4 (3): 237-309.

Ringbom, H. \& Jarvis, S. 2009. The Importance of Cross-Linguistic Similarity in Foreign Language Learning. In M.H. Long \& C.J. Doughty (eds.), The Handbook of Language Teaching. Chichester: Wiley-Blackwell: ıo6-ıв8.

Roberts, C. 20I2. Information Structure in Discourse: Towards an Integrated Formal Theory of Pragmatics. Semantics and Pragmatics 5: I-69.

Sжвø, K.J. 2004. Conversational Contrast and Conventional Parallel: Topic Implicatures and Additive Presuppositions. Journal of Semantics 2I (2): 199-217.

StUtTERHeIm, C. von 2003. Linguistic Structure and Information Organisation. The Case of Very Advanced Learners. In S.H. Foster-Cohen \& S. Pekarek-Doehler (eds.), EUROSLA Yearbook. Amsterdam - Philadelphia: J. Benjamins. Vol. 3: 183-206.

StUtTerheim, C. von \& CARroll, M. (in press). Texts as Answers to Questions: Information Structure and its Grammatical Underpinnings in Narratives in German and English (Topic and Anaphoric Linkage). In M. SteInbach \& A. HüBL (eds.), Linguistic Foundations of Narration in Spoken and Sign Languages. Amsterdam: J. Benjamins.

Stutterheim, C. von, Flecken, M. \& Carroll, M. (eds.) 20i3. International Review of Applied Linguistics in Language Teaching - IRAL: Principles of Information Organization in Language Use: On the L2 Acquisition of Complex Conceptual Structures 5I (2). Berlin: De Gruyter.

Stutterheim, C. von \& KLeIn, W. 2002. Quaestio and L-perspectivation. In C.F. GraumanN \& W. Kallmeyer (eds.), Perspective and Perspectivation in Discourse. Amsterdam: J. Benjamins: 59-88.

Sudhoff, S. 2008. Focus Particles in the German Middlefield. In A. Steube (ed.), The Discourse Potential of Underspecified Structures: Event Structures and Information Structure. Berlin - New York: De Gruyter: 439-459.

Tоміта, N. 2013. Strategies for Linking Information by German and Japanese Native Speakers and by German Learners of Japanese. International Review of Applied Linguistics in Language Teaching - IRAL SI (2): II7-I49.

Turco, G., Dimroth, C. \& Braun, B. 20I3. Intonational Means to Mark Verum Focus in German and French. Language and Speech 56 (4): 46I-49I.

Turco, G., Dimroth, C. \& Braun, B. 20I5. Prosodic and Lexical Marking of Contrast in L2 Italian. Second Language Research 3I (4): 465-49I. 


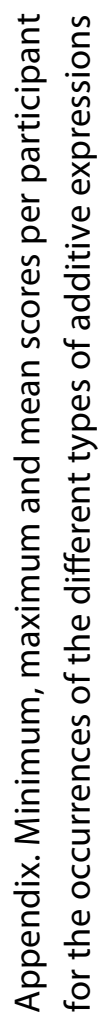

\begin{tabular}{|c|c|c|c|c|c|}
\hline \multirow{3}{*}{ 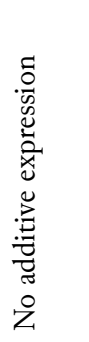 } & 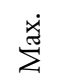 & $\underset{\substack{\infty \\
\dot{0}}}{0}$ & $\stackrel{\mathfrak{o}}{0}$ & $\tilde{o}$ & $\begin{array}{l}\widehat{\Delta} \\
\stackrel{0}{0}\end{array}$ \\
\hline & $\sum_{\Sigma}^{\Xi}$ & 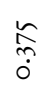 & $\begin{array}{l}\stackrel{\infty}{\circ} \\
\stackrel{0}{0}\end{array}$ & $\begin{array}{l}\text { f } \\
\text { Oे }\end{array}$ & $\begin{array}{l}\text { } \\
\text { âd } \\
0\end{array}$ \\
\hline & $\dot{\Sigma}$ & $\circ$ & $\circ$ & $\circ$ & $\circ$ \\
\hline \multirow[b]{3}{*}{ 节 } & 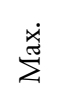 & $\begin{array}{l}\hat{0} \\
\stackrel{0}{0} \\
0\end{array}$ & $\begin{array}{l}\hat{\delta} \\
\stackrel{0}{0}\end{array}$ & $\underset{\tilde{\aleph}}{\stackrel{0}{0}}$ & \\
\hline & 志 & ग̃. & ¿̊ & $\begin{array}{l}\infty \\
0 \\
0 \\
0\end{array}$ & $\begin{array}{l}\overrightarrow{\hat{O}} \\
\dot{0}\end{array}$ \\
\hline & $\dot{\Xi}$ & $\circ$ & $\circ$ & $\circ$ & $\circ$ \\
\hline \multirow{3}{*}{ 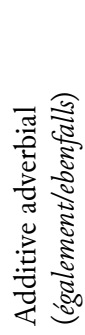 } & $\stackrel{\dot{x}}{\stackrel{m}{厶}}$ & $\stackrel{+}{\circ}$ & $\underset{\hat{\sigma}}{\hat{0}}$ & $\circ$ & $\begin{array}{l}0 \\
0 \\
0\end{array}$ \\
\hline & ¿ & $\begin{array}{l}I \\
0\end{array}$ & $\begin{array}{l}\hat{\overrightarrow{0}} \\
\dot{0}\end{array}$ & $\circ$ & $\begin{array}{l}\tilde{D} \\
0 \\
0 \\
0\end{array}$ \\
\hline & $\dot{\Xi}$ & $\circ$ & $\circ$ & $\circ$ & 0 \\
\hline \multirow{3}{*}{ 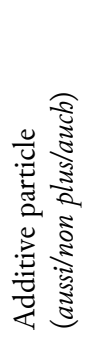 } & 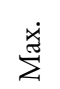 & $\underset{\substack{\hat{0} \\
\stackrel{0}{0}}}{ }$ & - & $r$ & - \\
\hline & $\stackrel{\widetilde{\Xi}}{\Sigma}$ & $\stackrel{\infty}{\stackrel{\infty}{0}}$ & $\begin{array}{l}\hat{\sigma} \\
0 \\
0\end{array}$ & $\begin{array}{c}\infty \\
\infty \\
0 \\
0\end{array}$ & $\underset{\hat{d}}{\hat{i}}$ \\
\hline & $\dot{\Sigma}$ & $\circ$ & $\begin{array}{l}\stackrel{1}{0} \\
\stackrel{0}{0}\end{array}$ & $\stackrel{\mathfrak{o}}{0}$ & 0 \\
\hline & & 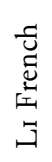 & 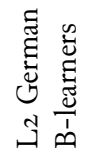 & 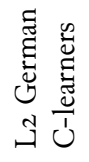 & 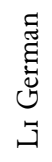 \\
\hline
\end{tabular}

